\title{
SZABAD ÉS VIRTUÁLIS HANGTERÜ LOKALIZÁCIÓS FELADATOK: LÁTÓK ÉS LÁTÁSSÉRÜLTEK KÉPESSÉGEINEK ÖSSZEHASONLÍTÓ VIZSGÁLATA
}

\author{
Szerzők: \\ Répás József \\ Gábor Dénes Főiskola \\ Wersényi György \\ Széchenyi István Egyetem
}

Első szerző e-mail címe:

repas@gdf.hu

\author{
Lektorok: \\ Pántya Péter \\ Nemzeti Közszolgálati Egyetem \\ Krizsán Zoltán \\ Nemzeti Közszolgálati Egyetem \\ Schéder Veronika \\ Debreceni Egyetem \\ Mező Katalin \\ Debreceni Egyetem
}

Répás József és Wersényi György (2015): Szabad és virtuális hangterü lokalizációs feladatok, látók és látássérültek képességeinek képességeinek összehasonlító vizsgálata. Különleges Bánásmód, I. évf. 2015/3. szám, 5-20. DOI 10.18458/KB.2015.3.5

\begin{abstract}
Absztrakt
Jelen tanulmány látó és látássérült személyek hanglokalizációs képességeire fókuszál. Minta: $n=59$ (50 látó és 9 látássérült) személy, $s 30$ személy a virtuális hangtér vizsgálatának esetében. Módszer: visszhangmentes szobában Leybold 58707 piezo hangforrást használtunk, virtuális hangtér szimuláció esetében az Alice szoftvert alkalmaztuk a hanglokalizáció vizsgálatakor. Eredmény: szabad hangtérben nincs különbség a látók és a látássérültek hanglokalizációs teljesítménye között. A lokalizációs bizonytalanság nagyobb a virtuális valóság szimulátor alkalmazásakor.
\end{abstract}

Kulcsszavak: virtuális valóság, süketszoba, lokalizáció

Diszciplina: gyógypedagógia

\begin{abstract}
FREE- AND VIRTUAL SOUND FIELD LOCALIZATION TASKS: COMPARATIVE STUDY OF SIGHTED AND VISUALLY IMPAIRED PERSONS

The present study focuses on the examination of sound localization abilities of sighted and visually impaired persons. Sample: $n=59$ (50 sighted and 9 visually impaired) persons, and 30 sighted persons. Method: we used Leybold 58707 piezo sound source in an anechoic room, and in case of simulation of virtual sound field, we used the Alice software in order to examine sound localization. Result: there is no significant difference between sound localizational achievements of sighted and visually impaired persons in free sound field. The localizational uncertainity is higher when we apply virtual reality simulator.
\end{abstract}

Keywords: virtual reality, anechoic room, localization

Discipline: special education 
Az emberi halláskutatás része a térhallás-, irányhallás-vizsgálatok fajtái, különösen az olyan lehallgatási lokalizációs tesztek, amelynek során ennek pontosságát vizsgáljuk. Korábban végeztünk olyan tájékozódási és orientációs feladatokat, amelyek alkalmasak látók és látássérültek lokalizációs képességeinek összehasonlítására (Répás, 2012; Répás, Wersényi, Kovács, 2013a; Répás, Wersényi, Kovács, 2013b). Ilyen feladatok voltak az egyenestartás, sarok-észlelés, aminek alapjai a mindennapi életben is előfordulnak, látóknál és látássérülteknél egyaránt, azonban a látók szemeinek elfedése komoly nehézséget tud okozni a végrehajtás során. Célunk a két csoport lokalizációs képességeinek vizsgálata és eredményeik statisztikai összehasonlítása volt.

Szabadtéri vizsgálatok után szabad hangtérben, süketszobai körülmények között végeztünk lokalizációs teszteket. Szabad hangtérnek nevezzük röviden a „,végtelen kiterjedésü, homogén levegőteret, amelyben a hang nem verödik vissza és nem hajlik el” (Net1). Ilyen térben „a hullámterjedést nem befolyásolja semmilyen elnyelö vagy visszaverö felület, azaz a hanghullám a forrásból a tér minden irányában elhajlás, törés és visszaverődés nélkül terjed" (Net2). Ilyen térben kellett a résztvevőknek a lokalizációs feladatokban minél jobb eredményt elérni.

A hangforrás helyének meghatározhatóságát lokalizációnak nevezzük. Degenhardt és Murol (1992) a mozgástréning vakok számára címü müvében leszögezi, hogy a látássérülteknek „meg kell tanulniuk a hangforrást lokalizálni, irány és távolság szerint...”.

„A lokalizáció annyit jelent, hogy képesek vagyunk a hangforrások helyzetét a fejhez rögzített koordinátarendszerben meghatározni. Ez csak véges pontossággal lehetséges, így az ún. lokalizációs bizonytalanság meghatározása az elsődleges cél. Ez nagyban függ a jel és a környezet paramétereitől, és általában a helyes iránytól való eltérés fokában adjuk meg (J. Blauert, 1969; J. C. Makous, J. C. Middlebrooks, 1990; J. C. Middlebrooks, D. M. Green, 1991). A hallás lehető legjobb felbontóképessége a szemben irányban található, 3-5 fok körüli a bizonytalanság mértéke" (Wersényi, 2007, 3. o.).

„Az irányérzékelés két legfontosabb paramétere a füljelek közötti (interaurális) szint- és időeltérések. Amelyik fülben hangosabb és/vagy előbb érkezik be a jel, azt közelebbinek fogjuk érzékelni. Az agy a hallásérzet helye és a hullám ismertetőjegyei között létesít kapcsolatot a lokalizáció közben. Ha a jellemzők megváltoznak, helyváltoztatás-érzet léphet fel. Lokalizációs bizonytalanság az a legkisebb helyváltoztatás, amit a hallórendszer érzékelni tud, úgy, hogy a fülben történt változás már kiértékelhető" (Répás, Wersényi és Kovács, 2013a).

Egy látássérült személy számára a környezetben jelen levő térbeli sajátosságok akusztikus érzékelése két kategóriába sorolható:

- A hangkibocsátó tárgyak lokalizációja: pl. emberek, autók, telefon.

- A hangokat ki nem bocsátó tárgyak lokalizációja: pl. egy fal, sarok, ajtónyílás (Répás, Wersényi és Kovács, 2013a, 74. o.).

$\mathrm{Az}$ ismertetésre kerülő módszerek a hangkibocsátó tárgyak lokalizációja csoportba tartoznak.

\section{A) Szabad hangterü lokalizációs feladat}

Az első szabad hangterü lokalizációs feladat egy klasszikus, abszolút lokalizációs tesztet jelentett, amely során az alanyoknak különféle hangforrásirányokat kellett a horizontális síkban azonosítaniuk.

\section{Módszer}

A süketszoba egyik sarkában került elhelyezésre egy Leybold 58707 típusú piezo hangforrás -minden esetben az alanyok fülével egy magasságban került beállításra. Körülötte 
egy koordinátarendszert helyeztünk el, az eltérések pontos leolvashatósága miatt. A koordinátarendszer vízszintes és függőleges irányban $\pm 10^{\circ}$-ig volt skálázva. Az alanyok (látók letakart szemmel) egy forgatható széken ültek, lézerpointerrel az ujjukon. Annak érdekében, hogy a látók se emlékezetből mutassanak a hangforrásra, a széken ülő alanyt néhányszor jobbra, majd balra forgattuk, véletlenszerüen. Miután a térbeli orientációs képességüket elvesztették, a forgatható széket $0^{\circ}$ (szemben irány), $-45^{\circ}$ (baloldalra fordítva, a hangforrás a jobb kéz felől), $-90^{\circ}$ (baloldalra fordítva, a hangforrás a jobb kéz felől), $45^{\circ}$ (jobboldalra fordítva, a hangforrás a bal kéz felől), $90^{\circ}$ (jobboldalra fordítva, a hangforrás a bal kéz felől) irányokba állítottuk. Ezután 5 másodperc hosszúságú fehérzaj vizsgálójelet sugároztunk, aminek irányát kellett meghatározniuk az ujjukra erősített lézerpointer segítségével (lásd 1. ábra). Az eltérések a koordinátarendszerről vízszintes és függőleges irányban, fokonként, könnyen leolvashatóak voltak. $10^{\circ}$-nál nagyobb eltérés esetén (amikor az alany nem tudott a táblára mutatni), a hibát rögzítettük.

1. ábra: Látó alany, letakart szemmel, lézerpointerrel az ujján, horizontális síkban azonosítja a hangforrást (forrás: Szerzök)

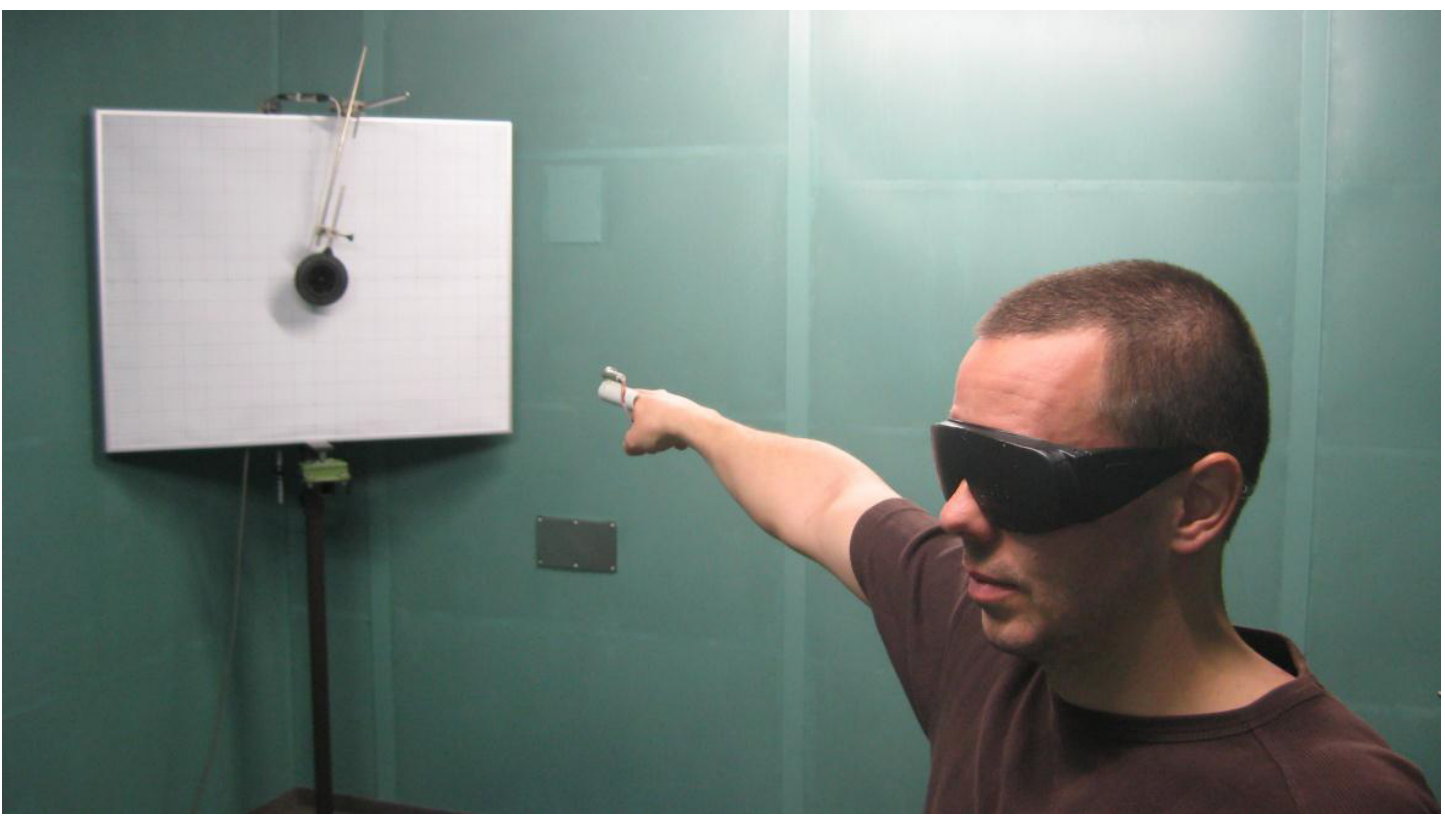

\section{Minta}

A feladatot 50 látó ( 35 férfi, 15 nő) és 9 látássérült (4 férfi, 5 nő) résztvevő teljesítette. A látók átlagos életkora 30,44 év, a szórása 13,41 volt, a legfiatalabb résztvevő 13, a legidősebb résztvevő 71 éves volt. A látássérültek átlagos életkora 48,56 év, szórása 13,02 volt, a legfiatalabb résztvevő 27 éves, a legidősebb résztvevő 62 éves volt. A résztvevők korának eloszlását a 2. ábra mutatja.

\section{Eljárás}

A látó résztvevők közepes mintaszáma, valamint a látó résztvevők korának széles spektruma miatt a férfi és női összehasonlítás mellett átlagéletkor alatti (fiatal) és feletti összehasonlítást is végeztünk. Látássérülteknél ilyen hasonló felosztás nem készült a résztvevők korlátozott száma miatt. 
2. ábra: Bal oldali ábrán a látó résztvevők korának megoszlása, jobb oldali ábrán a látássérült résztvevők korának megoszlása látható. Vízszintes tengelyen a kor, függöleges tengelyen a résztvevők száma látható (forrás: Szerzök)

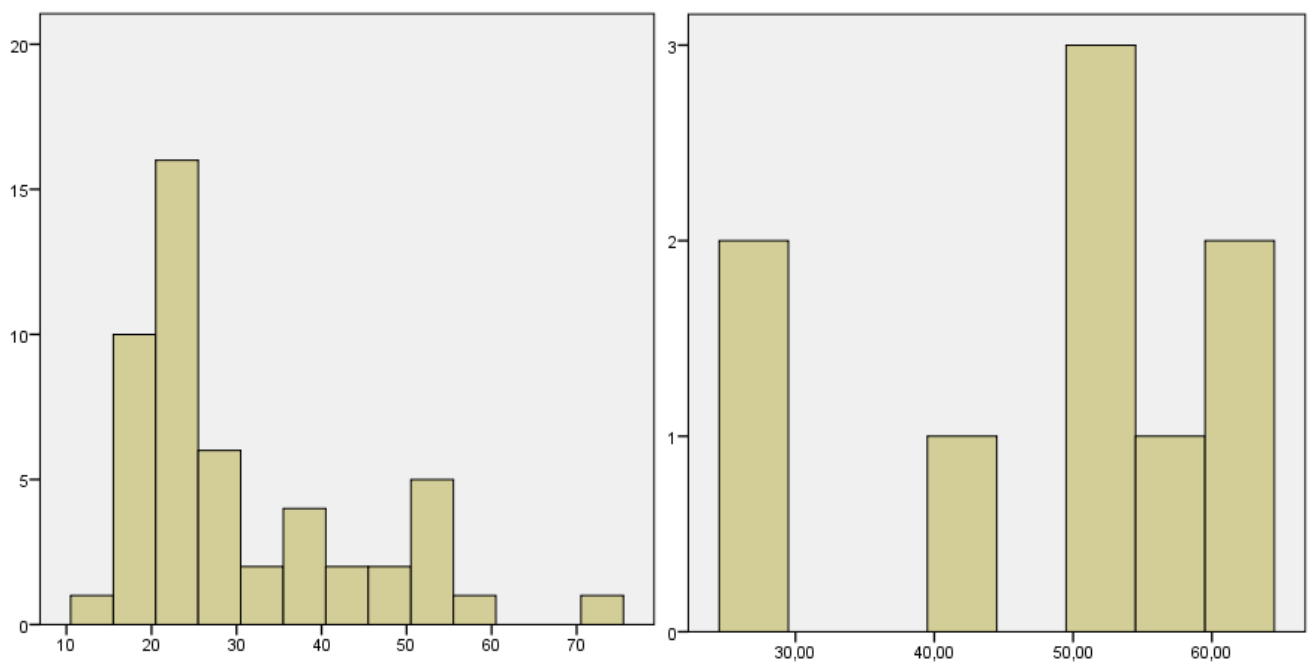

A 2. ábrából is látható, valamint a Kolomogorov-Smirnov normalitásvizsgálat is azt mutatja, hogy az életkorok eloszlása nem normális. Az eloszlások illeszkedésének vizsgálatára szolgáló Q-Q ábrán (lásd 3. ábra) is látható, hogy a pontok az egyenes körül szóródnak, vagyis nem normális eloszlásról van szó.

3. ábra Bal oldali $Q-Q$ ábra vízszintes tengelyén a látó résztvevök kora, függöleges tengelyen a sztenderd normális eloszlás változóját ábrázoltuk, a jobb oldali ábrán a látássérült résztvevök korát, függöleges tengelyen a sztenderd normális eloszlás változóját ábrázoltuk (forrás: Szerzök)
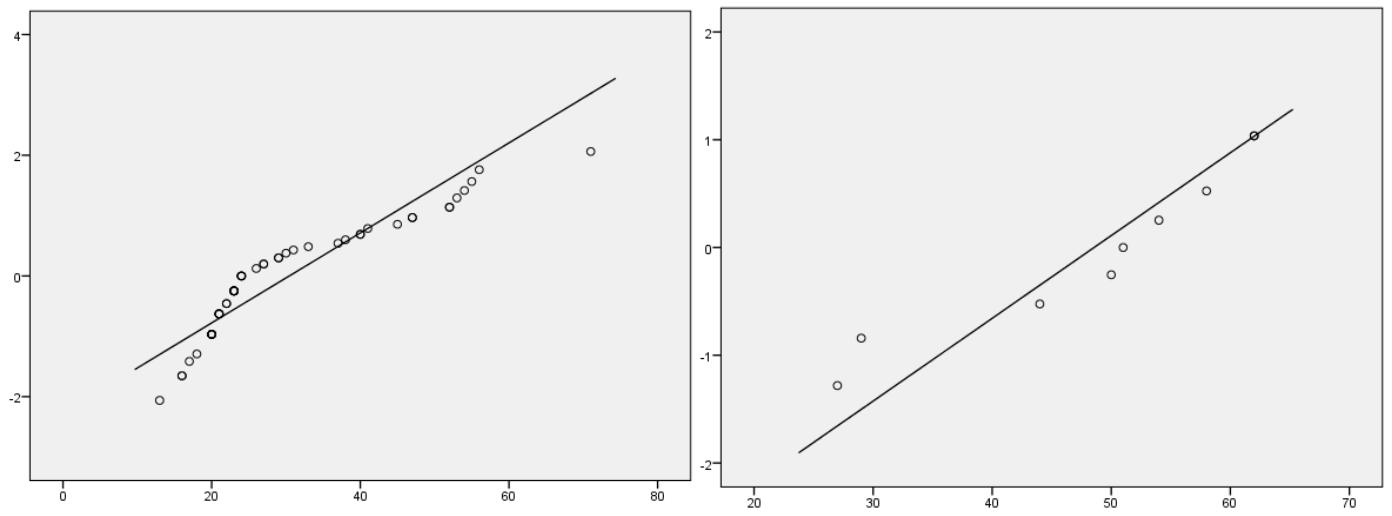

\section{Eredmények}

Látók és látássérültek találati arányát az 1. táblázat mutatja. Látható, hogy az 50 látó résztvevő közül -90-os irányból (baloldalra fordítva, a hangforrás a jobb kéz felől, mint az 1. 
ábrán) 72 \%-os találati arányt kaptunk. Látássérülteknél ez az arány valamivel kevesebb, 67 $\%$. Megfigyelhető, hogy látó férfiak ebből az irányból kis mértékben jobban teljesítettek, $74 \%$, míg a nök estén ez az arány $67 \%$.

1. táblázat: Látók és látássérültek találati aránya, vagyis a hangforrás lokalizációját $\pm 10^{\circ}$ os hibahatáron belül teljesítette (Forrás: Szerzők)

\begin{tabular}{|c|c|c|c|c|c|c|}
\hline \multirow{3}{*}{$\begin{array}{c}\text { Résztvevők } \\
\text { (fó) }\end{array}$} & \multicolumn{5}{|c|}{ Látók } & \multirow{2}{*}{$\begin{array}{c}\text { Látássérülttek } \\
\text { Összes }\end{array}$} \\
\hline & Összes & Férfi & Nő & Fiatal & Idős & \\
\hline & 50 & 35 & 15 & 32 & 18 & 9 \\
\hline \multicolumn{7}{|c|}{$-90^{\circ}$} \\
\hline Találat & $72 \%$ & $74 \%$ & $67 \%$ & $72 \%$ & $72 \%$ & $67 \%$ \\
\hline Nincs találat & $28 \%$ & $26 \%$ & $33 \%$ & $28 \%$ & $28 \%$ & $33 \%$ \\
\hline \multicolumn{7}{|c|}{$-45^{\circ}$} \\
\hline Találat & $74 \%$ & $71 \%$ & $80 \%$ & $72 \%$ & $78 \%$ & $67 \%$ \\
\hline Nincs találat & $26 \%$ & $29 \%$ & $20 \%$ & $28 \%$ & $22 \%$ & $33 \%$ \\
\hline \multicolumn{7}{|c|}{$0^{\circ}$} \\
\hline Találat & $78 \%$ & $77 \%$ & $80 \%$ & $78 \%$ & $78 \%$ & $89 \%$ \\
\hline Nincs találat & $22 \%$ & $23 \%$ & $20 \%$ & $22 \%$ & $22 \%$ & $11 \%$ \\
\hline \multicolumn{7}{|c|}{$45^{\circ}$} \\
\hline Találat & $62 \%$ & $60 \%$ & $67 \%$ & $69 \%$ & $50 \%$ & $56 \%$ \\
\hline Nincs találat & $38 \%$ & $40 \%$ & $33 \%$ & $31 \%$ & $50 \%$ & $44 \%$ \\
\hline \multicolumn{7}{|c|}{$90^{\circ}$} \\
\hline Találat & $54 \%$ & $54 \%$ & $53 \%$ & $56 \%$ & $50 \%$ & $44 \%$ \\
\hline Nincs találat & $46 \%$ & $46 \%$ & $47 \%$ & $44 \%$ & $50 \%$ & $56 \%$ \\
\hline
\end{tabular}

A -45-os irányban látók esetén javult a találati arány (74 \%), látássérülteknél változatlan maradt. Ebből az irányból a nők és az idősek a $74 \%$-os átlag felett teljesítettek, előbbiek $80 \%$, utóbbiak $78 \%$-ot értek el. Ezen találatiarány-javulások azt mutatják, hogy ebből az irányból valamivel könnyebb a hangforrást lokalizálni.

$0^{\circ}$-os, vagyis szemben a hangforrással további javulás figyelhető meg. Látók esetén a találati arány $78 \%$, látássérültek esetén pedig $89 \%$. Ennek fényében elmondható, hogy a hangforrást a szemben irányban tudják a látók és látássérültek is legkönnyebben, legnagyobb találati arány mellett azonosítani. A látó nők ebben a feladatban is kicsivel az átlag felett teljesítettek (80\%).

$45^{\circ}$-os irányban, vagyis jobboldalra fordítva, amikor a hangforrás a bal kéz felöl esik, a találati arány romlik mind látók, mind látássérültek esetén. Látók $62 \%$, látássérültek $56 \%$. A szemben irányhoz mért jelentős (16\% és 33\%) találatiarány-csökkenést vélhetően az okozza, hogy a jobb kéz mutató ujjára erősített lézerpointerrel a test előtt részben átnyúlva, keresztben kell a hangforrást azonosítani, ami nagymértékben rontja a találati arányt. Ebben az irányban a nök és a fiatalok teljesítettek jobban (67\% és 69\%).

$90^{\circ}$-os irányból, vagyis jobboldalra fordítva tovább romlik a találati arány azzal, hogy a jobb kéz mutató ujjára erősített lézerpointerrel a test előtt teljesen átnyúlva, keresztben kell a hangforrást azonosítani. Látók ebből az irányból 54\%-os találati arányt értek el, míg a látássérültek csupán $44 \%$-ost.

Mivel a szemben irányban tapasztaltunk látóknál (78\%) és látássérülteknél (89\%) is magas találati arányt, ezért a találati pontosság ismertetését ennél az iránynál kezdjük. A 4. ábrán 
leolvashatók az egyes koordináták, ahová látók és látássérültek beazonosították a hangforrást (látók narancsszínnel, látássérültek kék színnel vannak jelölve). Megfigyelhető, hogy több résztvevő vagy a vízszintes, vagy a függőleges irányt határozta meg jól, mutatott rá az egyik tengelyre, s csupán a másik iránynál van kisebb-nagyobb eltérés.

4. ábra: Látók (narancsszín) és látássérültek (kék szín) által mutatott irányok a $0^{\circ}$-os, szemben irányban (Forrás: Szerzők)

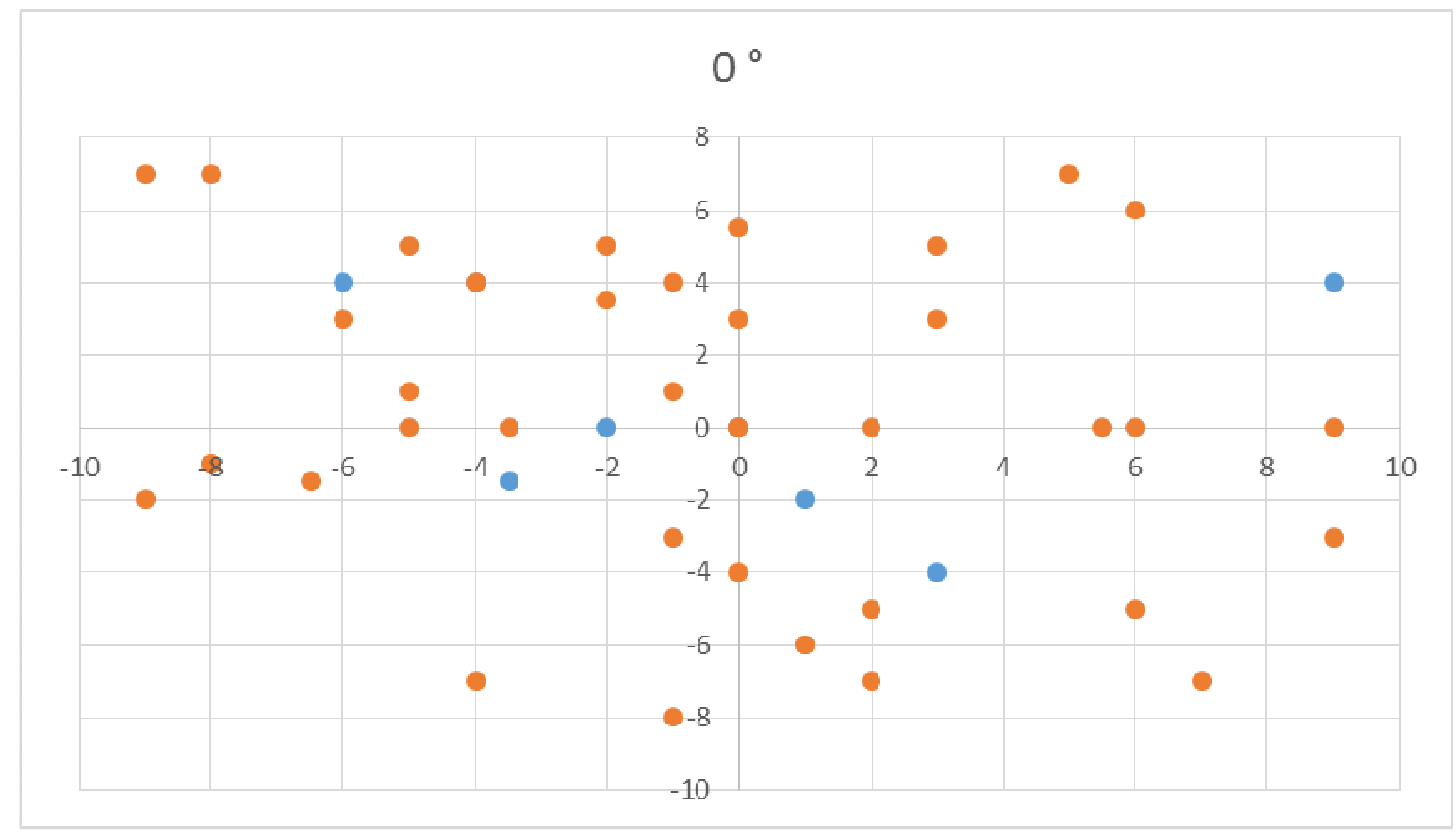

Mind a négy síknegyedbe mutattak a résztvevők - az 5. ábrán lévő koordinátarendszeren az egyes tengelyekre és a negyedekre való mutatás százalékos megoszlása látható. Az 1. síknegyedbe a látók 10\%-a a látássérültek 13\%-a mutatott. A 2. síknegyedbe közel azonos arányban (látók 25\%, látássérültek 26\%) mutattak. Látók esetén megegyezik a 3. és 4. síknegyed találati aránya (18\%), látássérültek esetén a 3. síknegyed aránya az 1. síknegyedével egyezik meg, a 4. síknegyedbe a résztvevők 25\%-a mutatott. Látók 23\%-a mutatott valamelyik tengelyre (15\% az x-tengelyre, $8 \%$ az y-tengelyre), látássérültek 13\%-a mutatott az x-tengely negatív tartományára. A látók 5\%-a, a látássérültek 13\%-a azonosította pontosan a hangforrást.

A 2. táblázatban látható, hogy a látók találatai az alábbiak szerint oszlanak meg $-90^{\circ}$-os irányból: az 1. síknegyedbe 25\%, a 2. síknegyedbe 11\%, a 3. síknegyedbe 19\%, a 4. síknegyedbe $31 \%$ mutatott. Az x-tengelyre 3-3\%, az y-tengelyre $6 \%$, a célba pedig $3 \%$ mutatott. Hasonló eredményeket láthatunk $90^{\circ}$-os irányból: az 1. síknegyedbe $26 \%$, a 2 . síknegyedbe $11 \%$, a 3. síknegyedbe $22 \%$ mutatott, kivéve a 4 . síknegyedet, ahová $7 \%$, az xtengelyre 15 és $4 \%$, az y-tengelyre 11 és $4 \%$, a célba pedig 3\% mutatott. A látássérültek többsége az 1 . síknegyedbe mutatott, függetlenül az irányoktól. $\pm 90^{\circ}$-os irányban a találatok $50 \%$-a, $45^{\circ}$-os irányból a találatok $60 \%$-a volt ebben a síknegyedben.

Látássérültteknél $45^{\circ}$-os irányból $20 \%$-os találati arány látható a célnál, azonban ez az eredmény megtévesztő lehet, mivel ebben az irányban a találati arány csupán 56\%-os volt, ami azt jelenti, hogy a 9 fö látássérült közül egy fö, aki célba talált, jelenti a $20 \%$-os találati arányt. 
5. ábra: Bal oldali ábrán a látók, jobb oldali ábrán a látássérültek $0^{\circ}$-os, szemben irányban való megoszlások láthatóak (Forrás: Szerzők)
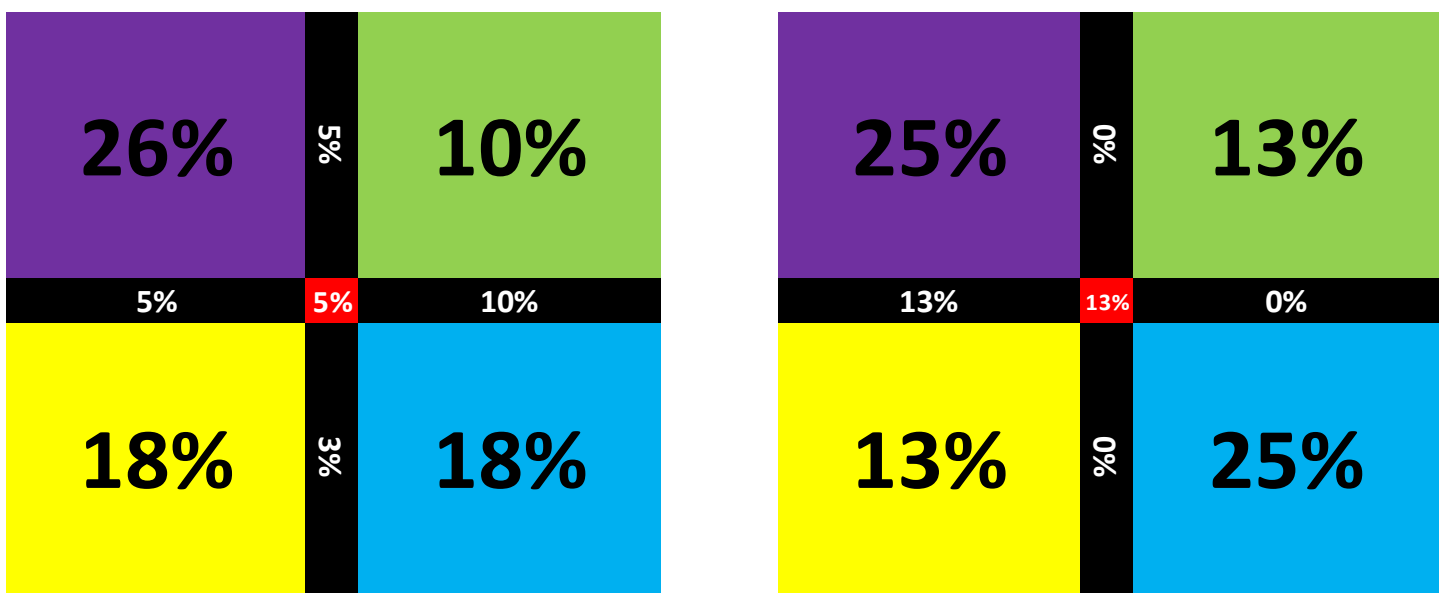

2. táblázat: Látók és látássérülltek különböző irányokban való megoszlásai (forrás: Szerzők)

\begin{tabular}{|c|c|c|c|c|c|c|c|c|c|}
\hline 胥 & 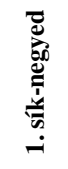 & 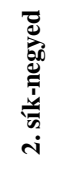 & 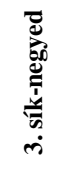 & 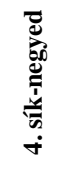 & 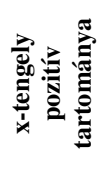 & 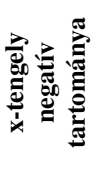 & 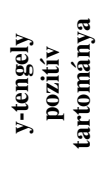 & 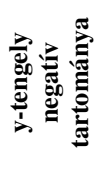 & ঠ \\
\hline \multicolumn{10}{|c|}{ Látók } \\
\hline$-90^{\circ}$ & $25 \%$ & $11 \%$ & $19 \%$ & $31 \%$ & $3 \%$ & $3 \%$ & $0 \%$ & $6 \%$ & $3 \%$ \\
\hline$-45^{\circ}$ & $41 \%$ & $8 \%$ & $11 \%$ & $24 \%$ & $11 \%$ & $0 \%$ & $3 \%$ & $0 \%$ & $3 \%$ \\
\hline $0^{\circ}$ & $10 \%$ & $26 \%$ & $18 \%$ & $18 \%$ & $10 \%$ & $5 \%$ & $5 \%$ & $3 \%$ & $5 \%$ \\
\hline $45^{\circ}$ & $13 \%$ & $10 \%$ & $35 \%$ & $10 \%$ & $0 \%$ & $6 \%$ & $10 \%$ & $13 \%$ & $3 \%$ \\
\hline $90^{\circ}$ & $26 \%$ & $11 \%$ & $22 \%$ & $7 \%$ & $15 \%$ & $4 \%$ & $11 \%$ & $4 \%$ & $0 \%$ \\
\hline \multicolumn{10}{|c|}{ Látássérültek } \\
\hline$-90^{\circ}$ & $50 \%$ & $0 \%$ & $0 \%$ & $17 \%$ & $17 \%$ & $17 \%$ & $0 \%$ & $0 \%$ & $0 \%$ \\
\hline$-45^{\circ}$ & $17 \%$ & $0 \%$ & $17 \%$ & $17 \%$ & $50 \%$ & $0 \%$ & $0 \%$ & $0 \%$ & $0 \%$ \\
\hline $0^{\circ}$ & $13 \%$ & $25 \%$ & $13 \%$ & $25 \%$ & $0 \%$ & $13 \%$ & $0 \%$ & $0 \%$ & $13 \%$ \\
\hline $45^{\circ}$ & $60 \%$ & $20 \%$ & $0 \%$ & $0 \%$ & $0 \%$ & $0 \%$ & $0 \%$ & $0 \%$ & $20 \%$ \\
\hline $90^{\circ}$ & $50 \%$ & $50 \%$ & $0 \%$ & $0 \%$ & $0 \%$ & $0 \%$ & $0 \%$ & $0 \%$ & $0 \%$ \\
\hline
\end{tabular}

A látók találatai alapján az egyes síknegyedekre számított átlagos eltérések az egyes irányokból a 6. ábrán láthatóak. Megfigyelhető, hogy az 1 . síknegyedben $0^{\circ}$ és $90^{\circ}$-os irányból, valamint a $-45^{\circ}$ és $-90^{\circ}$-os irányból közel azonos a vízszintes és függőleges irányú eltérés. A 2. és 3 . síknegyedben a $90^{\circ}$ és $45^{\circ}$ irányban közel azonos a vízszintes és függőleges irányú eltérés.

A látássérültek találatai alapján, az egyes síknegyedekre számított átlagos eltérések az egyes irányokból a 7. ábrán láthatóak. Megfigyelhető, hogy az 1. síknegyedben $45^{\circ}$ és $90^{\circ}$-os irányból közel azonos a vízszintes és függőleges irányú eltérés. $0^{\circ}$-os irányból mindegyik síknegyedben látható átlagos eltérés, azonban a találatok alacsony aránya miatt $90^{\circ}$ és $45^{\circ}$-os irányból csupán az 1 . és 2 . síknegyedben volt találat, így átlagos eltérés is. Hasonlóan a $-45^{\circ}$ os irányhoz, itt az 1. és 3. síknegyedben volt találat. 
6. ábra: Látók találatai alapján számított átlagos eltérései az egyes irányokból (Forrás: Szerzők)

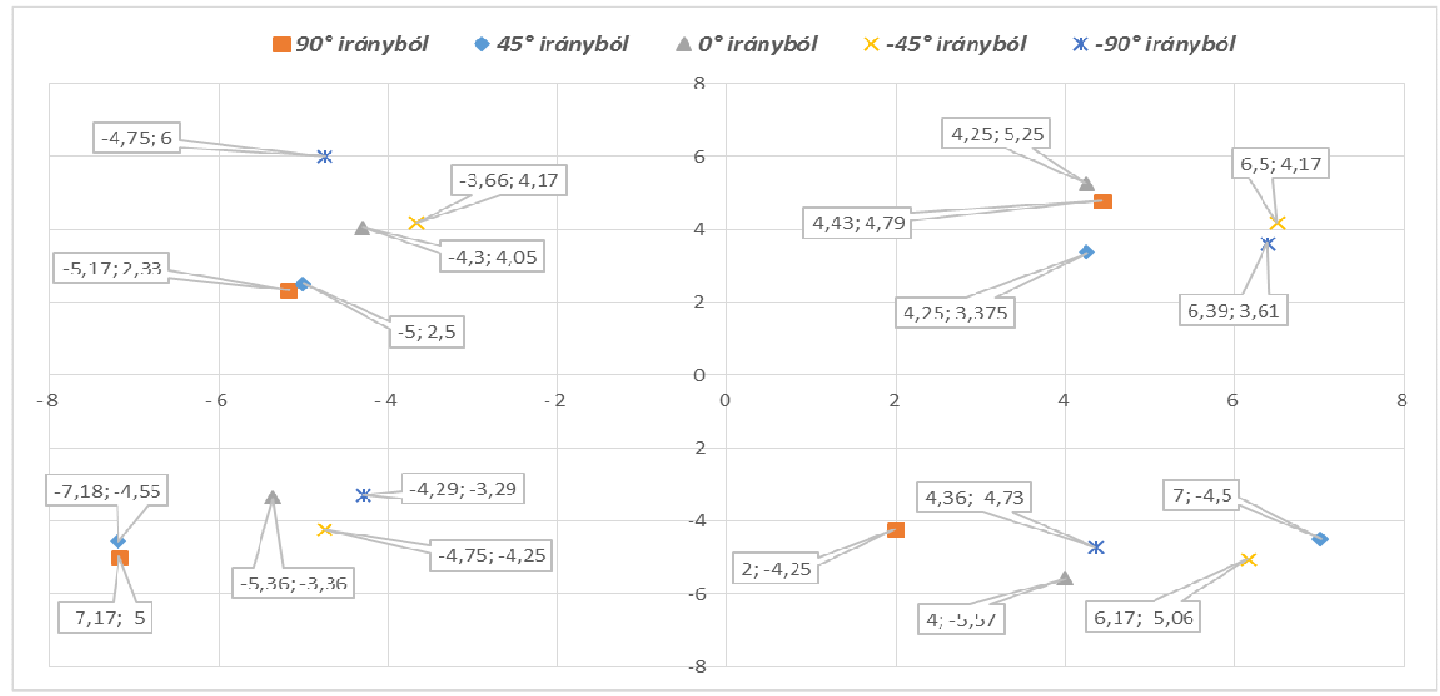

7. ábra: Látássérültek találatai alapján számított átlagos eltérései az egyes irányokból (Forrás: Szerzők)

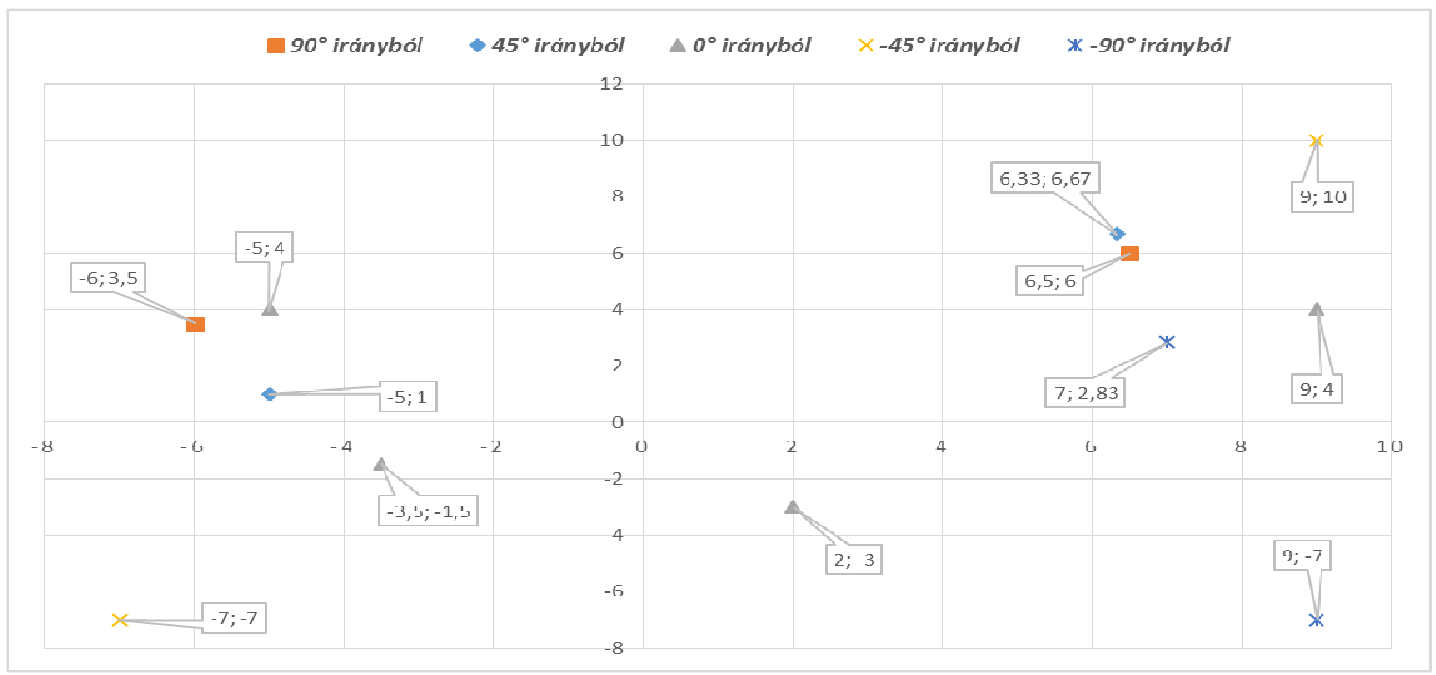

\section{Megvitatás}

A látók és látássérültek síknegyedenkénti átlagos eltéréseit összehasonlítva megállapítható, hogy a látók és látássérültek között nincs jelentős különbség, vagyis egyik csoport tagjai sem képesek pontosabban lokalizálni a hangforrást.

A látók eredményei $90^{\circ}$-os irányból kis mértékben jobbak az 1. és 3. síknegyedben, $0^{\circ}$-os irányból az 1 . és 3. síknegyedben, $-45^{\circ}$-os és $-90^{\circ}$-os irányokból az 1 . síknegyedben. A látássérültek eredményei $0^{\circ}$-os irányból kis mértékben jobbak a 3. és 4 . síknegyedben. 


\section{Korlátozások}

A látássérültekkel való lokalizációs vizsgálatok elvégzése a körülmények miatt nehézkesebb, a tesztekben látók segítségével is megállapíthatóak azok az általános következtetések, amik alapján az alapkutatás eredményeit felhasználva készíthetőek látássérültek lokalizációjának segítésére szolgáló eszközök.

\section{Konklúziók}

A megtervezett mérési módszer alkalmas látók és látássérültek lokalizációs képességeinek összehasonlítására. Mindkét csoport tagjai a horizontális síkban jellemző 3-5ºs lokalizációs bizonytalansággal teljesítették a feladatot. Megállapítható, hogy a látók és látássérültek lokalizációs képességei között nincs szignifikáns különbség, vagyis a jövőbeli kísérletekben első körben elegendő lehet a látók képességeinek vizsgálata, és az eredmények alapján látássérültekre is érvényes következtetések vonhatóak le.

\section{B) Virtuális hangterü lokalizációs feladat}

„A virtuális valóság szimulátor gyüjtőnév alatt megtaláljuk a látvány, a hangélmény, sőt a tapintás szimulációját is modern rendszerek esetében. Ennek részeként a hangtér létrehozása fejhallgatón keresztül történik és célja az autentikus hangtér leképezés. Hangforrásokat hozunk létre, irányinformációval látjuk el őket és olyan akusztikus környezetet igyekszünk megvalósítani, amely a lehető legjobban hasonlít a valóságra. A legfontosabb paraméter ebben a hangforrások helyének meghatározhatósága, a lokalizáció, az irányinformáció pontos átvitele" (Wersényi, 2007, 1. o.).

\section{Módszer}

A hallásfolyamat résztvevői: külső fül, középfül, a belső fül és az agy (J. Blauert, 1983; W. M. Hartmann, 1999). „A külső fül a dobhártyáig tart, a beérkező akusztikai hullám mechanikai rezgésbe hozza azt. A középfülben ez a mechanikai rezgés terjed a hallócsontokon át a csigáig. A belső fülben a csigában található folyadék és a baziláris membrán rezgései végzik a frekvenciatranszformációt és az idegi impulzusok előállításẤt az agy számára. A térbeli hallás számára a külső fül vizsgálata a legfontosabb (Shaw, 1974; Mehrgart és Mellert, 1977; Hammershøi és Møller, 1991). A külső fül müszaki leírása, mérnöki megragadása annak átviteli függvényével történik. A komplex átviteli függvényt az angol elnevezésböl HRTF-nek (Head-Related Transfer Function) rövidítjük (Wersényi, 2007, 1. o.). A HRTF-függvény alapvetően egy irányfüggő szürő ami, definíció szerint a hangforrástól a dobhártyáig tartó átviteli utat írja le. Így a HRTF-függvényeket a dobhártya helyén kell mérni, rögzíteni. A dobhártya helyén mikrofont elhelyezni azonban nagyon nehéz feladat, ami pontatlanságot visz a mérésekbe (Tóth, 2013).

\section{Eszközök}

A virtuális hangtér szimulációt egy MATLAB alatt fejlesztett Alice nevü program segítségével végeztük. A program egy hangfájlt különbözö HRTF készletek alapján lát el irányinformációkkal, úgy, hogy az a hallgató számára egy jól meghatározható irányból hallatszódjon. 


\section{Eljárás}

A 8. ábrán látható, számítógépen futó programban megnyitunk egy bemeneti hangfájlt (bal felső sarok Load gomb), aminek megjelenik idő és spektrum képe. Ezt a hangfájlt a kiválasztott HRTF készlet alapján, a beállítások szerinti irányinformációkkal látja el a program. A tesztek során hajas, sapkás, ruhás és szemüveges HRTF adatbázisokat használtunk, amik korábban, ugyanezen a müfejen lettek mérve. A hangfájl tényleges feldolgozását a Process gombbal lehet elindítani, a számítási müveletek végrehajtása után aktívvá válik „Play stereo sound” és „Save stereo sound” gomb, így az irányinformációkkal ellátott hangfájl lejátszható és menthető.

Lehetőség van meghatározni például, hogy horizontális vagy mediális síkban történik a mérés (horizontal simulation, medial simulation), de fejméret alapján is módosítható az irányinformációkkal ellátott kimeneti hangfájl.

A feladatban fejhallgató-kiegyenlített fehérzaj bemeneti jelet használtunk. A fejhallgatókiegyenlítés azért fontos, mert a fejhallgató frekvenciafüggő csillapítást, szürést végez, ami módosítja a mérési eredményeket, ezért kompenzálni szükséges. Ez a kompenzáció elvégezhető a programon belül és attól függetlenül is. Mi az utóbbi lehetőséget választottuk, így a programba már egy elöszürt hangfájlt töltöttünk be.

Az 5 másodperc hosszúságú, 16 bit kvantálási hosszal, és 44,1 KHz mintavételezési frekvenciával (CD-minőség) felvett fehérzaj jelet 10 alkalommal rögzítettük egy Sennheiser HD650 típusú fejhallgatóval és müfejjel, majd átlagoltuk. A rögzített hangfájlokból átlagolás után MATLAB-ban, inverz FIR szürővel elkészítettük az ALICE programban alkalmazott, fejhallgató-kiegyenlített bemeneti hangfájlunkat.

A virtuális valóság szimulátor által előállított hangfájlok jobb és bal irányból az alábbi szögekben készültek: $0^{\circ}, 10^{\circ}, 20^{\circ}, 30^{\circ}, 60^{\circ}, 90^{\circ}, 120^{\circ}, 150^{\circ}$ és $180^{\circ}$, (9. ábra). Ezeket a Sennheiser HD650 típusú fejhallgatón keresztül játszottuk le a résztvevő alanyoknak.

A fenti, valamint a korábbi látók-látássérültek lokalizációs képességeit összehasonlító feladatokban is beigazoltuk, hogy nincs szignifikáns különbség a két csoport lokalizációs képességeiben.

8. ábra: Alice nevü, Virtuális hangtér szimulátor program képernyöképe (forrás: Tóth, 2013)

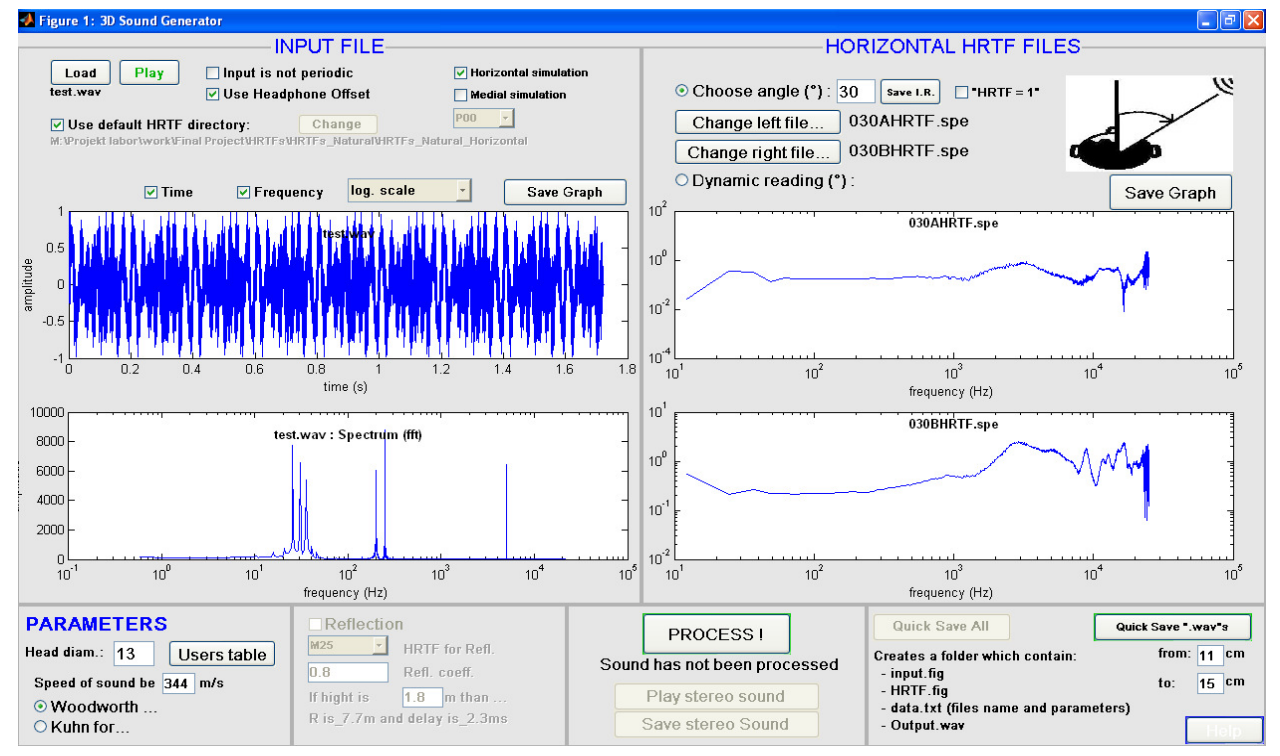


9. ábra: Virtuális valóság szimulátor által elöállitott hangfájlok (forrás: Wersényi és Répás, 2014)

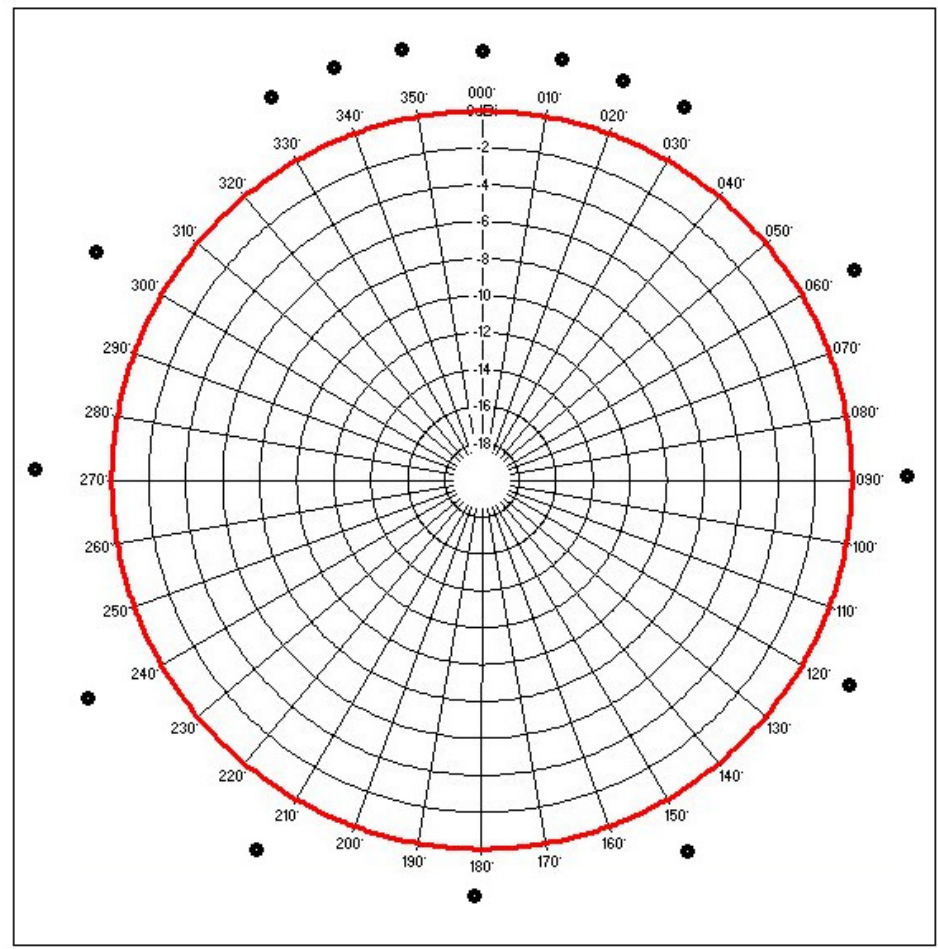

\section{Minta}

Ebben a feladatban 30 látó ( 22 férfi, 8 nő) vett részt, minden résztvevő 4 részfeladatot teljesített. Első részfeladat esetén normál (kopasz müfej) HRTF segítségével készült irányinformációval rendelkező hangokat kellett azonosítani. Második esetben hajas (parókát tettünk a müfejre, hogy a haj módosító szerepét vizsgáljuk) HRTF, harmadik esetben szemüveges (szemüveg szerepét vizsgáltuk) HRTF, negyedik esetben pedig sapkás (sapka szerepét vizsgáltuk) HRTF segítségével készült irányinformációval rendelkező hangokat kellett azonosítani. Célunk a különbözö HRTF készletekből készült hangfájlok lokalizálhatóságának és pontosságának vizsgálata volt.

A résztvevők átlagos életkora 10 és 62 év közötti, átlagos életkor 31,23 év, szórás 12,95. A 10. ábrából is látható, valamint a Kolomogorov-Smirnov normalitásvizsgálat is azt mutatja, és a Q-Q ábrán is látható, hogy a pontok az egyenes körül szóródnak, vagyis nem normális eloszlásról van szó.

\section{Eredmények}

A 3. táblázatban látható, hogy az egyes irányokból, különböző HRTF készletek esetén milyen találati arányokat mértünk. $0^{\circ}$-os irányú hangnak normál esetben a résztvevők $77 \%$-a tudott valamilyen irányt meghatározni, pontos találatot, vagyis a helyes, szemben irányt azonban csak 19\%-uk határozott meg. Hajas HRTF esetén a résztvevők 78\%-a tudott valamilyen irányt meghatározni, pontos találatot azonban csak 31\%-uk határozott meg, ami ebböl az irányból a legnagyobb. Szemüveges HRTF esetén a résztvevők $77 \%$-a tudott valamilyen irányt meghatározni, pontos találatot azonban csak $26 \%$-uk határozott meg. A legjobb találati arányt ebből az irányból sapkás HRTF esetén érték el a résztvevők, 84\%-uk tudott valamilyen irányt meghatározni, pontos találatot azonban csak $24 \%$-uk határozott meg. 
10. ábra: Bal oldali ábrán a látó résztvevők korának megoszlása. Vízszintes tengelyen a kor, függöleges tengelyen a résztvevők száma látható. A baloldali $Q-Q$ ábra vízszintes tengelyén a látó résztvevők kora, függöleges tengelyen a sztenderd normális eloszlás változóját ábrázoltuk (forrás: Szerzők)
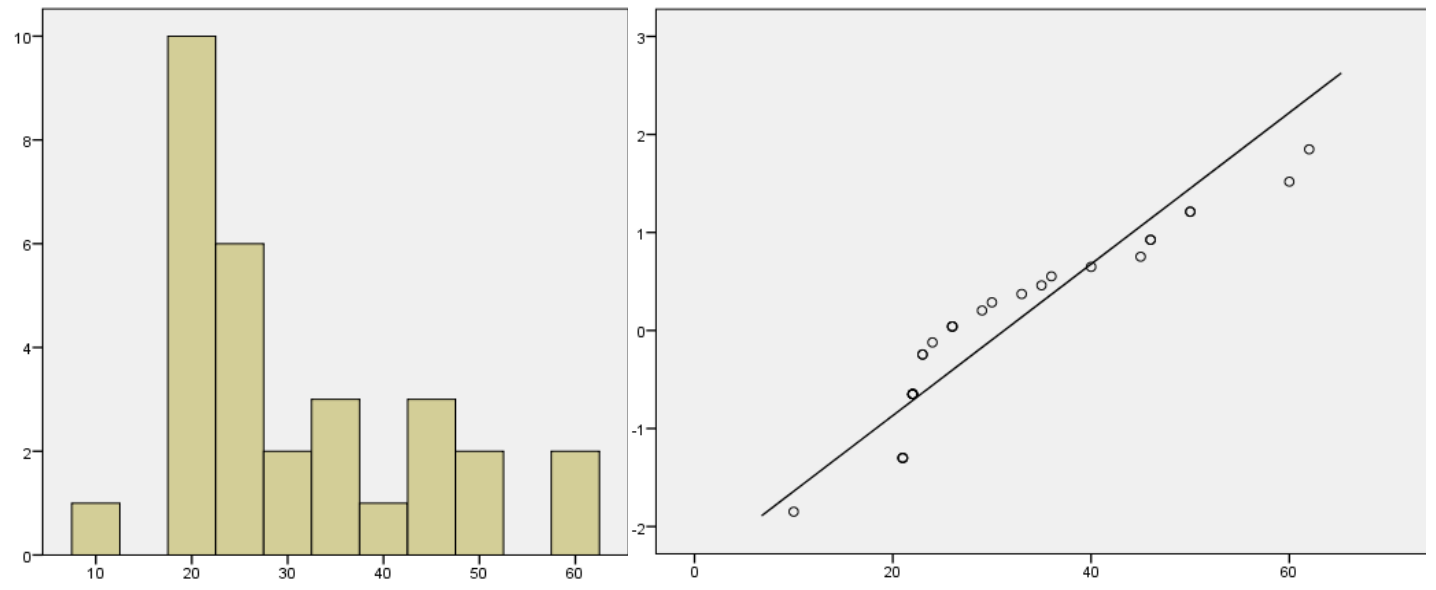

3. táblázat: Normál, hajas, szemüveges és sapkás HRTF-ek találati aránya (forrás: Szerzők)

\begin{tabular}{|c|c|c|c|c|c|c|c|c|}
\hline & \multicolumn{2}{|c|}{ Normál } & \multicolumn{2}{|c|}{ Hajas } & \multicolumn{2}{c|}{ Szemüveges } & \multicolumn{2}{c|}{ Sapkás } \\
\hline Irányok & Találat (\%) & Pontos találat (\%) & Találat (\%) & Pontos találat (\%) & Találat (\%) & Pontos találat (\%) & Találat (\%) & Pontos találat (\%) \\
\hline $\mathbf{0}$ & $77 \%$ & $19 \%$ & $78 \%$ & $31 \%$ & $77 \%$ & $26 \%$ & $84 \%$ & $24 \%$ \\
\hline 10 & $93 \%$ & $7 \%$ & $90 \%$ & $0 \%$ & $93 \%$ & $7 \%$ & $87 \%$ & $8 \%$ \\
\hline 20 & $100 \%$ & $0 \%$ & $97 \%$ & $7 \%$ & $97 \%$ & $7 \%$ & $90 \%$ & $0 \%$ \\
\hline 30 & $93 \%$ & $4 \%$ & $100 \%$ & $0 \%$ & $97 \%$ & $3 \%$ & $97 \%$ & $17 \%$ \\
\hline 60 & $93 \%$ & $11 \%$ & $100 \%$ & $10 \%$ & $97 \%$ & $17 \%$ & $97 \%$ & $10 \%$ \\
\hline 90 & $93 \%$ & $25 \%$ & $97 \%$ & $48 \%$ & $93 \%$ & $54 \%$ & $97 \%$ & $48 \%$ \\
\hline 120 & $100 \%$ & $50 \%$ & $100 \%$ & $67 \%$ & $97 \%$ & $41 \%$ & $97 \%$ & $55 \%$ \\
\hline 150 & $97 \%$ & $59 \%$ & $100 \%$ & $50 \%$ & $97 \%$ & $66 \%$ & $97 \%$ & $38 \%$ \\
\hline 180 & $80 \%$ & $57 \%$ & $79 \%$ & $72 \%$ & $78 \%$ & $59 \%$ & $78 \%$ & $60 \%$ \\
\hline 210 & $97 \%$ & $34 \%$ & $97 \%$ & $52 \%$ & $93 \%$ & $50 \%$ & $90 \%$ & $48 \%$ \\
\hline 240 & $97 \%$ & $38 \%$ & $100 \%$ & $50 \%$ & $97 \%$ & $41 \%$ & $97 \%$ & $55 \%$ \\
\hline 270 & $100 \%$ & $63 \%$ & $100 \%$ & $40 \%$ & $97 \%$ & $34 \%$ & $97 \%$ & $28 \%$ \\
\hline 300 & $97 \%$ & $7 \%$ & $100 \%$ & $13 \%$ & $97 \%$ & $7 \%$ & $97 \%$ & $17 \%$ \\
\hline 330 & $93 \%$ & $18 \%$ & $93 \%$ & $11 \%$ & $97 \%$ & $24 \%$ & $97 \%$ & $17 \%$ \\
\hline 340 & $97 \%$ & $21 \%$ & $97 \%$ & $24 \%$ & $97 \%$ & $24 \%$ & $93 \%$ & $18 \%$ \\
\hline 350 & $87 \%$ & $12 \%$ & $90 \%$ & $7 \%$ & $97 \%$ & $14 \%$ & $97 \%$ & $7 \%$ \\
\hline
\end{tabular}

Valamivel jobb a helyzet $180^{\circ}$-os irányban, normál esetben a résztvevők $80 \%$-a tudott valamilyen irányt meghatározni, pontos találatot, vagyis a helyes, szemben irányt azonban csak 57\%-uk határozott meg. A legjobb találati arányt ebböl az irányból hajas HRTF esetén a résztvevők 79\%-a ért el, pontos találatot pedig 71\%-uk határozott meg, ami ebböl az irányból a legnagyobb. Szemüveges HRTF esetén a résztvevők $78 \%$-a tudott valamilyen irányt meghatározni, pontos találatot azonban csak 59\%-uk határozott meg. Sapkás HRTF esetén érték el a résztvevők, 78\%-uk tudott valamilyen irányt meghatározni, pontos találatot azonban csak $60 \%$-uk határozott meg. 
A $0^{\circ}$-os irányból jövő hangot háromszor, a $180^{\circ}$-os irányból jövő hangot négyszer játszottuk le, annak érdekében, hogy az elöl-hátul döntés hibát is vizsgáljuk. Elöl-hátul döntési hibának nevezzük azt az esetet, amikor az elölröl érkező hangot az alany hátulról hallja, hátul-elöl döntési hibának nevezzük azt az esetet, ha a hátulról jövő hang esetében azt elölről hallja.

A 11. ábrán a normál HRTF készlet eredményei láthatóak, a bal oldali hisztogramon látható, hogy a $0^{\circ}$-os, elöl irány esetén kiemelkedően sok $180^{\circ}$-os érték szerepel, ami azt jelenti, hogy sok elöl-hátul döntési hibát vétettek az alanyok. Az összes találati arány 42\%-a elöl-hátul döntési hiba volt. A jobb oldali hisztogramon látható, hogy a $180^{\circ}$-os, elöl irány esetén nincs olyan sok $0^{\circ}$-os érték, ami azt jelenti, hogy hátul-elöl döntési hibát kevesebbet vétettek az alanyok, csupán a találatok $15 \%$-a volt ilyen tévedés.

11. ábra: $0^{\circ}$-os (bal oldali ábra) és $180^{\circ}$-os (jobb oldali ábra) irányok találati megoszlásai (forrás: Szerzők)
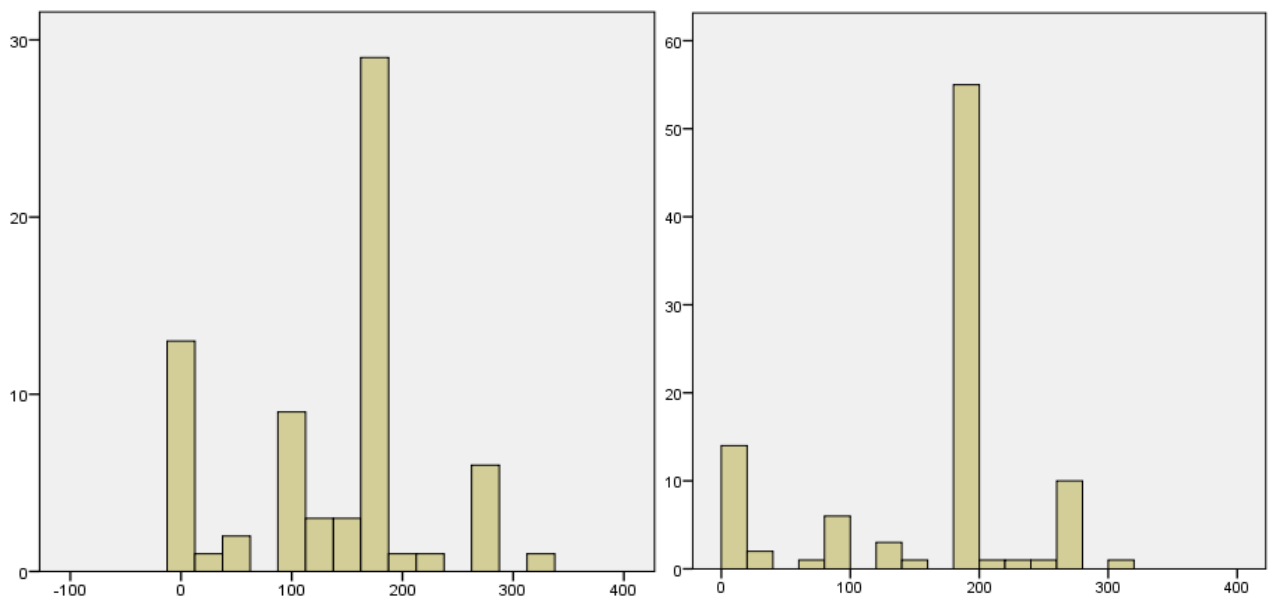

Kiemelkedő találati és magas pontos találati arányt $270^{\circ}$-os irányban, vagyis baloldal irányból tapasztaltunk. Mind a négy HRTF készlet esetén közel 100\%-os találati arány figyelhető meg. Normál esetben a résztvevők 63\%-a tudott pontos irányt meghatározni. A másik három esetben azonban alacsony volt a pontos találati arány $(40 \%, 34 \%, 28 \%)$.

Jobb oldal irányból, vagyis $90^{\circ}$-ból is magas találati és közepes pontos találati arányt tapasztaltunk. Normál HRTF készletnél 25\%, hajas HRTF készletnél 48\%, szemüveges HRTF készletnél 54\%-os, sapkás HRTF készletnél 48\%-os volt a pontos találati arány.

A 12. ábra baloldali diagramon látható, hogy $0^{\circ}$-os irányban a résztvevők 19\%-ban jól lokalizálták, 42\%-ban hátulról, 13\%-ban jobboldalról, 9\%-ban baloldalról hallották a hangot. A maradék 17\%-ban egyéb irányokat határoztak meg. A jobboldali diagramon látható, hogy a $180^{\circ}$-os irányt a résztvevők 57\%-ban jól lokalizálták, 15\%-ban elölről, 6\%-ban jobboldalról, 10\%-ban baloldalról hallották a hangot. A maradék 12\%-ban egyéb irányokat határoztak meg.

A 4. táblázatban látható, hogy $0^{\circ}$-os és $180^{\circ}$-os irányokban a résztvevők milyen \%-os megoszlásban vétettek elöl-hátul vagy hátul-elöl hibát, valamint $90^{\circ}$-os és $270^{\circ}$-os irányban mutattak-e a helyes irány helyett az egyes HRTF készletek alkalmazásakor. Megfigyelhetö, hogy szemüveges HRTF alkalmazásakor $180^{\circ}$ irányt szimuláló hang esetén 59\%-ban jól lokalizálták azt, 13\%-ban elölröl, 13\%-ban jobboldalról, 3\%-ban baloldalról hallották a hangot. A maradék 12\%-ban egyéb irányokat határoztak meg. 
12. ábra: $0^{\circ}$-os (bal oldali ábra) és $180^{\circ}$-os (jobb oldali ábra) irány elöl-hátul, hátul-elöl hibák és egyéb irányokban való tévedés megoszlásai (forrás: Szerzők)

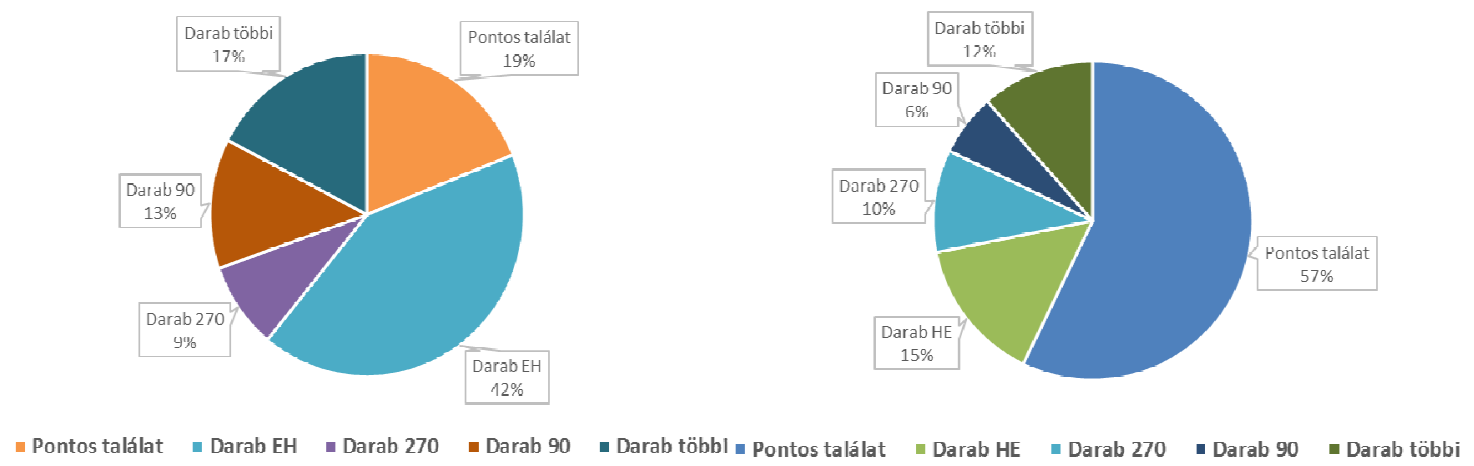

4. táblázat: Találatok megoszlása $0^{\circ}$ és $180^{\circ}$-os irányból, a különbözö HRTF készletek használata mellett (forrás: Szerzők)

\begin{tabular}{|c|c|c|c|c|c|c|}
\hline & Pontos találat & Darab EH & Darab HE & Darab 270 & Darab 90 & Darab többi \\
\hline \multicolumn{7}{|c|}{ Normál } \\
\hline 180 & $57 \%$ & - & $15 \%$ & $10 \%$ & $6 \%$ & $12 \%$ \\
\hline 0 & $19 \%$ & $42 \%$ & - & $9 \%$ & $13 \%$ & $17 \%$ \\
\hline \multicolumn{7}{|c|}{ Hajas } \\
\hline 180 & $72 \%$ & & $2 \%$ & $1 \%$ & $12 \%$ & $14 \%$ \\
\hline 0 & $31 \%$ & $41 \%$ & - & $11 \%$ & $14 \%$ & $3 \%$ \\
\hline \multicolumn{7}{|c|}{ Szemüveges } \\
\hline 180 & $59 \%$ & & $13 \%$ & $3 \%$ & $13 \%$ & $12 \%$ \\
\hline 0 & $26 \%$ & $49 \%$ & - & $1 \%$ & $22 \%$ & $1 \%$ \\
\hline \multicolumn{7}{|c|}{ Sapkás } \\
\hline 180 & $60 \%$ & - & $24 \%$ & $1 \%$ & $6 \%$ & $9 \%$ \\
\hline 0 & $24 \%$ & $59 \%$ & - & $5 \%$ & $3 \%$ & $9 \%$ \\
\hline
\end{tabular}

\section{Megvitatás}

A lokalizációs bizonytalanság a különbözö HRTF készletek alkalmazása során nem közelíti meg a szabad hangterü vizsgálatok eredményének 3-5ºs értékét.

A legjobban meghatározható irányok normál HRTF esetén: $270^{\circ}(63 \%$ találta el, átlag eltérés $\left.\left(-18^{\circ}\right)\right), 240^{\circ}\left(38 \%\right.$ találta el, átlag eltérés $\left.\left(3^{\circ}\right)\right), 210^{\circ}(34 \%$ találta el, átlag eltérés $\left.\left(21^{\circ}\right)\right), 150^{\circ}\left(59 \%\right.$ találta el átlag eltérés $\left.\left(3^{\circ}\right)\right), 120^{\circ}\left(50 \%\right.$ találta el, átlag eltérés $\left.\left(17^{\circ}\right)\right)$.

A legkevésbé meghatározható irányok normál HRTF esetén: $20^{\circ}(0 \%), 10^{\circ}(7 \%), 300^{\circ}$ $(7 \%), 30^{\circ}(4 \%), 350^{\circ}(12 \%), 60^{\circ}(11 \%)$.

A legjobban meghatározható irányok hajas HRTF esetén: $120^{\circ}(67 \%$ találta el, átlag eltérés $\left.\left(-10^{\circ}\right)\right), 240^{\circ}\left(50 \%\right.$ találta el, átlag eltérés $\left.\left(-10^{\circ}\right)\right), 210^{\circ}\left(52 \%\right.$ találta el, átlag eltérés $\left.\left(15^{\circ}\right)\right)$, $150^{\circ}\left(50 \%\right.$ találta el, átlag eltérés $\left.\left(-22^{\circ}\right)\right), 90^{\circ}\left(48 \%\right.$ találta el, átlag eltérés $\left.\left(21^{\circ}\right)\right)$.

A legkevésbé meghatározható irányok: $20^{\circ}(7 \%), 10^{\circ}(0 \%), 30^{\circ}(0 \%), 60^{\circ}(10 \%), 350^{\circ}$ (7\%). 
A legjobban meghatározható irányok szemüveges $\mathrm{HRTF}$ esetén: $150^{\circ}(66 \%$ találta el, átlag eltérés $\left.\left(-18^{\circ}\right)\right), 210^{\circ}\left(50 \%\right.$ találta el, átlag eltérés $\left.\left(20^{\circ}\right)\right), 90^{\circ}(54 \%$ találta el, átlag eltérés $\left(10^{\circ}\right)$.

A legkevésbé meghatározható irányok szemüveges $\mathrm{HRTF}$ esetén: $20^{\circ}(7 \%), 10^{\circ}(7 \%), 30^{\circ}$ (3\%), $300^{\circ}(7 \%)$.

A legjobban meghatározható irányok sapkás HRTF esetén: $120^{\circ}(55 \%$ találta el, átlag eltérés $\left.\left(-1^{\circ}\right)\right), 240^{\circ}\left(55 \%\right.$ találta el, átlag eltérés $\left.\left(4^{\circ}\right)\right), 90^{\circ}\left(48 \%\right.$ találta el, átlag eltérés $\left(11^{\circ}\right)$, $210^{\circ}\left(48 \%\right.$ találta el, átlag eltérés $\left(17^{\circ}\right)$.

A legkevésbé meghatározható irányok sapkás HRTF esetén: $20^{\circ}(0 \%), 10^{\circ}(8 \%), 60^{\circ}$ $(10 \%), 350^{\circ}(7 \%)$.

\section{Korlátozások}

A résztvevők közepes mintaszáma és az alkalmazott HRTF-ek számának korlátozottsága miatt nem lehet egyértelmüen meghatározni, hogy az alanyok lokalizációs képességei voltak az elvártnál alacsonyabbak, vagy az elkészült irányinformációval ellátott hangfájlok nem hordozták azt a mennyiségü információt, ami alapján a lokalizáció pontosabb és nagyobb arányú lett volna. További tesztek szükségesek annak érdekében, hogy vizsgálható legyen például a fejméret állításának szerepe.

\section{Konklúziók}

A bemutatott virtuális valóság szimulátor program által előállított kimeneti hangfájlok tartalmazzák azt a minimálisan szükséges irányinformációt, ami alapján az alanyok lokalizálhatják a forrás irányát. Különböző HRTF készletek lokalizálhatósága a fenti eredmények alapján eltérő, további vizsgálatokat kell végezni annak érdekében, hogy milyen mértékü irányinformációk szükségesek ahhoz, hogy a szabad hangterü vizsgálatoknál elért 3$5^{\circ}$-os lokalizációs bizonytalanságot megközelíthessük a virtuális valóság szimulátorral.

Az elért eredmények egy alapkutatás részei, melyek felhasználhatóak lesznek olyan látássérültek számára fejlesztett segédeszközökben, amik a mindennapi életük megkönnyítéséhez alkalmazhatóak. Ilyen lehet például az „okos” közlekedési lámpa, mobil eszközzel történő navigáció (pl.: egyenes tartás), vagy a tárgyfelismerés.

\section{Irodalom}

Blauert, J. (1969): Sound Localization in the median plane. Acoustica 22, 205-213.

Blauert, J. (1983): Spatial Hearing. The MIT Press, MA.

Degenhardt, H. és Murol, H. (1992). Mozgástréning vakok számára. Bárczi Gusztáv Gyógypedagógiai Főiskola, Budapest.

Hammershøi, D. és Møller, H. (1991): Free-field sound transmission to the external ear; a model and some measurement. DAGA'91, Bochum, pp. 473-476.

Hartmann, W. M. (1999): How we localize sound. Physics Today, 24-29.

Makous, J. C. és Middlebrooks, J. C. (1990): Two-dimensional sound localization by human listeners. J. Acoust. Soc. Am. 87(5), 2188-2200.

Mehrgart, S. és Mellert, V. (1977): Transformation characteristics of the external human ear. J. Acoust. Soc. Am. 61(6), 1567-1576.

Middlebrooks, J. C. és Green D. M. (1991): Sound localization by human listeners. Ann. Rev. Psychol. 42, 135-159.

Répás J. (2012): Látók és látássérültek összehasonlítása sarok-észlelés vizsgálatokban, akusztikai információk alapján. Bolyai Szemle 12.(1.) 169-180. 
Répás J., Wersényi Gy. és Kovács G. (2013a): Mérési eljárások kidolgozása látók és látássérültek lokalizációs képességeinek összehasonlítására. (ISBN:978-963-7158-05-6).

Répás J., Wersényi Gy. és Kovács G. (2013b): Látássérültek hallásképességeinek összehasonlító vizsgálata mérnöki és társadalomtudományi szempontból, Debreceni Müszaki Közlemények 12:(2) . 112-120.

Shaw, E. A. G. (1974): Transformation of sound pressure level from the free-field to the eardrum in the horizontal plane. J. Acoust. Soc. Am. 56(6), 1848-1861.

Tóth Z. (2013), diplomamunka: Virtuális valóság szimulátor programozása és tesztelése MATLAB alatt.

Wersényi Gy. (2007): Virtuális hangtérszimuláció és a binaurális technológia, Hiradástechnika, Vol. LXII, (2), 25-32.

Wersényi, Gy. és Répás, J. (2014): A Virtual Audio Environment for Testing DummyHead HRTFs modeling Real Life Situations Forum Acusticum. Krakow

\section{Internetes hivatkozások}

Net1: Szabad hangtér. Letöltve: 2015.10.15., Web: http://www.kislexikon.hu/szabad_hangter. html\#ixzz3qSFnGmr2

Net2: Szabad hangtér, Letöltve: 2015.10.15.Web:http://www.fonor.hu/files/letoltesek/ BME_ KJK_Zaj_4_Terjedes.pdfSkillsand 